\title{
Observations On The Current Status Of Internationalizing The Accounting Curriculum: Catalog Evidence
}

Gregory A. Claypool, (E-mail: gregclaypool@yahoo.com), Youngstown State University Fran M. Wolf, (E-mail: wolf1876@yahoo.com), Youngstown State University

\begin{abstract}
The last quarter century has witnessed the acceleration of the development of the global economy. This on-going development has caused profound changes in the way business is conducted and the skills needed by the executives leading this change. Recognizing the need to better prepare future corporate executives to function in this global environment, the American Assembly of Collegiate Schools of Business (AACSB), as part of a revision of its accreditation standards, included a curriculum standard requiring business schools to address the international dimension of business. To aid business schools in addressing this standard, the AACSB joined with the Consortium for International Studies Education to produce resource guides in 1987 for the functional areas of accounting, finance, management, and marketing. The accounting guide described two approaches that could be used to address the internationalization of the accounting curriculum. The freestanding approach would use a stand-alone international accounting course. The infusion approach would integrate international topics within other accounting courses. This paper assesses the extent that the accounting curriculum has been internationalized by reference to evidence obtained from the catalogs of ninety-six universities with AACSB-accredited business programs. Thirtyseven of these programs showed no catalog disclosure of international content of their accounting courses. The remaining fifty-nine programs revealed international content in their accounting courses to varying degrees, as discussed in the body of the paper.
\end{abstract}

\section{Introduction}

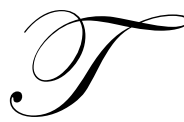

he increasingly global nature of the world economy is self-evident even to the casual observer. It seems that everyone is aware of the presence and impact of products and services marketed by foreign-based companies, especially as it impacts directly on their day-to-day lives and their own working status. Social concerns over the new dynamics of the global economy continue to be expressed vigorously, as evidenced by the fight over the North American Free Trade Agreement a few years ago and continued public protests at various world economic conferences. Business failures of large multinational companies have caused tremors to be felt worldwide, such as the 1998 failure of Long Term Capital Management and, more recently, Enron.

In the 1980s, the AACSB (then the American Assembly of Collegiate Schools of Business, now the Association to Advance Collegiate Schools of Business) undertook to revise its accreditation standards, in part to better reflect the increased globalization of business. Under the revised standards, the focus shifted to a mission-oriented approach. Henceforth, accredited business programs would need to demonstrate adherence to their own mission statements. With respect to curriculum, gone was a list of prescribed courses required to be in every institution's business curriculum. Instead, a generally-worded curriculum standard was issued, stating, "The purpose of the

Readers with comments or questions are encouraged to contact the authors via email. 
curriculum shall be to provide for a broad education preparing the student for imaginative and responsible citizenship and leadership roles in business and society - domestic and worldwide... There is no intention that any single approach is required to satisfy the worldwide dimension." ${ }^{1}$ To aid its member schools in their considerations of this worldwide dimension to the business curriculum, the AACSB collaborated with the Consortium for International Studies Education to publish resource guides for the functional areas of accounting, finance, management, and marketing. The resource guide for accounting ${ }^{2}$ identified two approaches for internationalizing the accounting curriculum: the free-standing approach and the infusion approach. In the free-standing approach, a separate international accounting course is used. Under the infusion approach, the international dimensions of topics traditionally addressed in standard accounting courses are covered in addition to the generally accepted accounting principles used by U.S. companies.

It should be noted that the curriculum standard cited above is for business programs. Thus, it is likely that AACSB-accredited business programs are demonstrating compliance with this standard through courses that all business majors take. Such an approach reduces the impetus for accounting programs to consider seriously the international aspects of the part of the curriculum required only of accounting majors. The purpose of this study is to assess the extent that accounting programs in AACSB-accredited institutions located in the United States have internationalized the accounting curriculum required of its majors. This assessment was made with reference to disclosures in college and university catalogs.

\section{The Study's Design \& Summary of Results}

The AACSB's web site was accessed to obtain the most current listing of all accredited business programs. After eliminating institutions located outside the United States, three hundred eighty-five colleges and universities located in the United States were identified. Ninety-six of these institutions were randomly selected for inclusion in the study. Of these ninety-six, forty possessed the additional accounting accreditation. The official catalogs of these institutions were examined by using the resources provided by College Source Online through its web site, www.collegesource.org. For each institution, the accounting courses required of accounting majors were identified. Then, course descriptions were read to determine if an international theme was prominent enough to merit mention in the courses' descriptions. All course descriptions within the accounting area were read, including elective courses. The presence of free-standing international accounting courses were also noted. A summary of the findings appears in the table below.

Table 1

\begin{tabular}{|l|c|c|}
\hline & $\begin{array}{c}\text { Accounting } \\
\text { Accreditation }\end{array}$ & $\begin{array}{c}\text { Business Program } \\
\text { Accreditation Only }\end{array}$ \\
\hline Free-standing required & 1 & 0 \\
\hline Free-standing available as elective & 7 & 5 \\
\hline International topic mentioned in required course description & 5 & 14 \\
\hline International topic mentioned in elective course description & 4 & 7 \\
\hline International topic mentioned in both required \& elective course descriptions & 1 & 2 \\
\hline Free-standing \& mentioned in required course description & 2 & 1 \\
\hline Free-standing \& mentioned in elective course description & 4 & 5 \\
\hline Free-standing \& mentioned in both required \& elective course descriptions & 1 & 0 \\
\hline No free-standing \& no mention in course descriptions & 15 & 22 \\
\hline
\end{tabular}

The examination of catalog disclosures revealed that twenty-six of the ninety-six programs surveyed offer a free-standing international accounting course. Twenty-five of these twenty-six offer the course as an elective; only one requires it. Fifteen of the twenty-six have the separate accounting accreditation in addition to the business accreditation; eleven have only the business accreditation. Fourteen of the twenty-six also mention an international theme in at least one other course description, although only five mention it in a required course; these fourteen pro- 
grams include the one accounting program that requires a free-standing accounting course. Twelve of the twenty-six offer the course as an elective and make no mention of an international theme in any other course.

Thirty-three accounting programs mention an international theme in at least one course in their programs, but do not offer a free-standing international accounting course. Twenty-two of these thirty-three programs include a reference to an international theme in at least one required accounting course; the other eleven disclose such a theme in at least one elective course. Ten of the thirty-three programs possess the separate accounting accreditation; twenty-three have the business accreditation only.

Thirty-seven institutions possessing AACSB accreditation for their business programs do not offer a freestanding international accounting course, nor to they mention an international theme in any of their course descriptions found in the catalog. Fifteen of these programs have the separate accounting accreditation; twenty-two possess the business accreditation only.

\section{Discussion}

Adherence to the AACSB's curriculum standard with respect to the worldwide dimension is not supported by this study. As stated above, thirty-seven accredited institutions disclose accounting curricula that do not include a free-standing international accounting course or any mention of international issues in the descriptions of other accounting courses. This is not surprising. The standard applies to the curriculum for all business students, not just accounting majors. Most institutions appear to be meeting this dimension of the standard through other parts of the business core courses rather than within the major courses. Nonetheless, the intent of AACSB was clear with the issuance of the resource guides. All functional areas were to consider how to best prepare their students for participation in the global marketplace. It is difficult for accounting programs to argue from the catalog evidence that this intent is being met when $38.5 \%$ of observed accounting programs had absolutely no mention of international topics.

There are at least two explanations for this. First, it may be that the catalog descriptions accurately portray a total lack of attention to international accounting topics. While the AICPA has recently vigorously promoted the adoption of a global credential, its own Uniform Certified Public Accountant exam has ignored international topics. The last disclosed CPA exam contained no questions with any international flavor; the most recent exam (November 2001) also was totally devoid of international coverage. When viewed from this perspective, academic accounting departments that are often judged, in part, on the success of their graduates on the CPA exam are simply adopting a rational and logical approach to delivering the accounting curriculum. Further, the resource guides were prepared to aid faculty in obtaining sufficient knowledge to be able to incorporate the international dimension into their courses. It was recognized by the AACSB that many business faculty members lacked adequate backgrounds to enable them to meet this goal. The guide recommended faculty workshops conducted by experts to help bring business faculty up to a satisfactory level of competence in this area. It is probable that many business schools opted, instead, for a more efficient approach by allocating faculty who already possessed competence in the international area to the business core courses. This approach would probably have been sufficient to satisfy the worldwide dimension of the curriculum standard. It would have ignored, however, developing international competence across the entire business faculty. Thus, international dimensions that could easily be infused into traditional accounting topics may not be making their way into the curriculum because faculty do not have the competence to include them.

Another explanation may be that the catalog descriptions do not fully portray what is actually occurring in the class. While many university catalogs include course descriptions that go into fairly extensive detail, others are short, concise overview statements designed to be just that.... short and concise. So, while it is observable in the present study whether or not a free-standing course exists, this study's methodology can only infer possible infusion of international topics if they are mentioned in the course description. Thus, it may well be that infusion is occurring in accounting courses taken by accounting majors, even though an international dimension is not mentioned in the courses' catalog descriptions.

It should be noted that three accounting programs in the study described unique, integrative approaches to delivering the accounting curriculum. Such integrative approaches would seem ideal for using the infusion ap- 
proach for coverage of international accounting topics. Only one of the three programs mentioned an international aspect in its description of these courses.

\section{Limitation and Conclusion}

As mentioned above, this study is obviously limited in its ability to assess the extent of use of the infusion approach. The limitation is obviously related to the study design used. Assessment of the extent of use of infusion is probably best assessed through the use of a survey instrument.

Accounting academics, business faculty, and the accounting industry as a whole should consider carefully the importance of the international dimensions of accounting. While the worldwide dimension of the AACSB's curriculum standard may easily be met through structuring the general business core courses, such an approach fails to address the international aspects of each functional business area.

\section{Endnotes}

1 American Association of Collegiate Schools of Business. AACSB Accreditation Council Policies Procedures and Standards 1987-88. IV. Curriculum, p. 28.

2 Mueller, G.G., Gernon, H., and Meek, G. A Resource Guide for Internationalizing the Business School Curriculum: Accounting. American Association of Collegiate Schools of Business and the Consortium for International Studies. 1987.

Notes 